\title{
Pengembangan Lembar Kerja Siswa untuk Menumbuhkan Kemampuan Pemecahan Masalah Matematis pada Materi Teorema Pythagoras
}

\author{
Yuriska Destania $^{1}$, Selvi Riwayati ${ }^{2}$ \\ ${ }^{1,2}$ Program Studi Pendidikan Matematika, Fakultas Ilmu Pendidikan, Universitas Muhammadiyah Bengkulu, \\ Jl. Bali Kota Bengkulu, Bengkulu, Indonesia \\ yuriskadestania@yahoo.com
}

\begin{abstract}
This research was aimed to compile and develop student worksheets (LKS) to practice the mathematical problem skills of grade VIII junior high school students on phytagoras material. The ability of the problem as the basic ability of learning in the 21 st century become important in the learning process. The 21 st century learning paradigm emphasizes the various abilities of students in finding out from sources, formulating problems, thinking analytically and collaborating and collaborating in solving problems. But still very minimal instructional materials capable of training the ability of students' problems, it is very necessary in development of teaching materials one LKS. This research is a development research which refers to the Thiangarajan development model or the 4-D model which has been modified into 3 stages, namely defining, designing and developing, with the aim of producing valid and practical Student Worksheets (LKS) to develop mathematical problems solving skills in the Pythagorean Theorem. The validity of the worksheets was obtained through a validation process with three competent validators, while the practicality were obtained by conducting limited trials of student worksheets to 10 students grade VIII. Based on this trial, a practicality score of $77.6 \%$ was obtained so that a valid and practical student worksheet was obtained to develop junior high school students' mathematical problem's solving abilities in the Pythagorean Theorem material.
\end{abstract}

Keywords: 4-D Models, Student Worksheets, Mathematical Problem Solving, Pythagorean Theorem

\begin{abstract}
Abstrak
Tujuan penelitian adalah menyusun dan mengembangkan lembar kerja siswa (LKS) untuk melatih kemampuan pemecahan masalah matematis siswa kelas VIII SMP pada materi phytagoras. Kemampuan pemecahan masalah sebagai kemampuan dasar pembelajaran pada abad ke-21 menjadi penting dalam proses pembelajaran. Paradigma pembelajaran abad 21 menekankan pada kemampuan siswa dalam mencari tahu dari berbagai sumber, merumuskan permasalahan, berpikir analitis dan kerjasama serta berkolaborasi dalam menyelesaikan masalah. Namun masih sangat minim bahan ajar yang mampu melatih kemampuan pemecahan masalah matematis siswa, maka sangat perlu dilakukangan pengembangan bahan ajar salah satunya LKS. Penelitian ini merupakan penelitian pengembangan yang mengacu pada model pengembangan Thiangarajan atau model 4-D yang telah dimodifikasi menjadi 3 tahap yaitu pendefinisian (Define), perancangan (Design) dan pengembangan (Development), dengan tujuan menghasilkan Lembar Kerja Siswa (LKS) yang valid dan praktis untuk menumbuhkan kemampuan pemecahan masalah matematis pada materi Teorema Pythagoras. Kevalidan dari LKS tersebut diperoleh melalui proses validasi bersama tiga validator yang kompeten, sedangkan kepratisan diperoleh dengan melakukan uji coba terbatas LKS yang telah valid tersebut kepada 10 siswa kelas VIII. Berdasarkan uji coba tersebut didapatkan skor kepraktisan 77,6\% sehingga diperoleh Lembar Kerja Siswa yang valid dan praktis untuk mumbuhkan kemampuan pemecahan masalah matematis siswa SMP pada materi Teorema Pythagoras.
\end{abstract}

Kata kunci: Model 4-D, Lembar Kerja Siswa, Pemecahan Masalah Matematis, Teorema Pythagoras

Copyright (c) 2021 Yuriska Destania, Selvi Riwayati

$\triangle$ Corresponding author: Yuriska Destania

Email Address: yuriskadestania@yahoo.com (Jl. Bali Kota Bengkulu, Bengkulu)

Received 30 Maret 2021, Accepted 08 March 2021, Published 12 April 2021

\section{PENDAHULUAN}

Pendidikan secara umum dapat dipahami sebagai upaya pengembangan potensi kemanusiaan secara utuh dan penanaman nilai-nilai sosial budaya yang diyakini oleh sekelompok masyarakat agar dapat mempertahankan hidup dan kehidupan secara layak (Teguh, 2014, p. 23). Secara sederhana 
pendidikan dapat dipahami sebagai suatu proses yang diperlukan untuk mendapatkan keseimbangan dan kesempurnaan dalam mengembangkan manusia. Oleh karena itu, pendidikan merupakan suatu hal yang sangat penting dalam menentukan kualitas kehidupan seseorang maupun menjadi cerminan kemajuan dari suatu bangsa. Mengingat pentingnya pendidikan maka perlu adanya peningkatan mutu pendidikan (Rusdi, 2014).

Berdasarkan tujuan pembelajaran tersebut maka guru sebagai pendidik memiliki peran dan tanggung jawab yang besar dalam membekali peserta didik dengan kemampuan- kemampuan yang berguna untuk mencapai tujuan pembelajaran. Salah satu kemampuan yang dimaksud adalah kemampuan pemecahan masalah matematis. Kemampuan pemecahan masalah matematis merupakan salah satu aspek ranah kognitif yang mencakup kemampuan siswa dalam menguasai sesuatu untuk menangkap makna dan arti dari materi yang dipelajari (Martin, 2000). Pemecahan masalah matematis merupakan landasan penting dalam menyelesaikan persoalan matematika maupun persoalan dalam kehidupan sehari-hari.

Riwayati dan Destania (2019) menjelaskan bahwa matematika merupakan salah satu mata pelajaran yang memegang peranan sangat penting dalam pendidikan, karena selain dapat mengembangkan penalaran logis, rasional, dan kritis serta memberikan keterampilan kepada mereka untuk mampu menggunakan matematika dan penalaran dalam memecahkan berbagai masalah dalam kehidupan sehari-hari maupun dalam mempelajari ilmu lain. Menurut Abdul Majid (2012), mengingat pentingnya proses pembelajaran matematika maka pendidik dituntut untuk mampu menyesuaikan, memilih, dan memadukan model pembelajaran yang tepat dalam setiap pembelajaran matematika. Oleh karena itu, diperlukan adanya perbaikan dalam pembelajaran matematika, seperti model pembelajaran yang digunakan dan sumber belajar agar siswa lebih tertarik untuk belajar matematika. Dalam Depdiknas (2005, p. 22), tujuan pembelajaran matematika sebagai berikut: (1). Melatih cara berpikir dan bernalar dalam menarik kesimpulan, (2). Mengembangkan aktivitas kreatif yang melibatkan imajinasi, intuisi dan penemuan dengan mengembangkan pemikiran divergen, orisinil, rasa ingin tahu, membuat prediksi, dan dugaan serta mencoba-coba, (3). Mengembangkan kemampuan memecahkan masalah, (4). Mengembangkan kemampuan menyampaikan informasi atau mengkomunikasikan gaagsan lain melalui pembicaraan lisan, catatan, grafik, peta dan menjelaskan gagasan.

Kemampuan pemecahan masalah sebagai kemampuan dasar pembelajaran pada abad ke-21 menjadi penting dalam proses pembelajaran. Paradigma pembelajaran abad 21 menekankan berpikir analitis dan kerjasama serta berkolaborasi dalam menyelesaikan masalah (Juwita \& Ariani, 2020). Sejalan dengan pendapat Sumartini (2016) bahwa kemampuan pemecahan masalah siswa menjadi salah satu komponen utama dalam aktivitas pemecahan masalah dalam kegiatan pembelajaran. Oleh karena itu, penting bagi guru merancang pembelajaran yang dapat melatih kemampuan pemecahan masalah siswa. Syaiful (2012) menegaskan bahwa kemampuan pemecahan masalah sangat penting dimiliki oleh setiap siswa karena pemecahan masalah merupakan tujuan umum pengajaran matematika bahkan sebagai jantungnya matematika, pemecahan masalah meliputi metode, prosedur, dan strategi merupakan 
proses inti dan utama dalam kurikulum matematika.

Menurut Hafiziani (2017), kemampuan pemecahan masalah matematis merupakan kegiatan memahami pemecahan masalah serta memilih strategi yang akan digunakan dengan benar dan tepat serta mampu menafsirkan solusinya, penempatan kegiatan pemecahan masalah merupakan proses pembelajaran matematika. Hal ini ikut ditegaskan oleh Hadi \& Radiyatul (2014) bahwa kemampuan menyelesaikan masalah merupakan tujuan umum pengajaran matematika yang mengandung pengertian bahwa matematika dapat membantu dalam memecahkan persoalan baik dalam pelajaran lain maupun dalam kehidupan sehari-hari.

Taufan (2018, p. 6) menyatakan bahwa pemecahan masalah dalam kurikulum matematika sangat dibutuhkan untuk menerapkan dan mengintegrasikan banyak konsep, keterampilan matematika serta membuat keputusan yang sangat penting untuk pengembangan konseptual, penempatan kegiatan pemecahan masalah dalam proses pembelajaran matematika. Oleh karena itu kemampuan pemecahan masalah ini menjadi tujuan umum pembelajaran matematika. Namun kenyataannya dilapangan masih sangat minim bahan ajar yang mampu melatih kemampuan pemecahan masalah matematis siswa. Olehkarena itu pengembangan bahan ajar untuk menumbuhkan kemampuan pemecahan masalah siswa sangat diperlukan, salah satu pengembangan bahan ajar yang dimaksud adalah pengembangan Lembar kerja Siswa (LKS).

Menurut Anindya Fajarin (2018) LKS adalah materi ajar yang dikemas secara integrasi sehingga memungkinkan siswa mempelajari materi tersebut secara mandiri. Adapun materi yang sering digunakan dalam kehidupan sehari-hari dan dapat melatih kemampuan siswa dalam memecahkan permasalahan dengan beberapa jawaban secara mandiri, salah satunya adalah materi phytagoras. Berdasarkan permasalahan di atas, maka perlu disusun dan dikembangkan lembar kerja siswa untuk melatih kemampuan pemecahan masalah matematis siswa kelas VIII SMP pada materi phytagoras. Tujuan penelitian adalah menghasilkan Lembar Kerja Siswa (LKS) matematika yang valid dan praktis untuk melatih kemampuan pemecahan masalah matematis siswa.

\section{METODE}

Penelitian ini adalah penelitian pengembangan (Reseach and Devolpment) yang merupakan metode penelitian yang berfungsi untuk memvalidasi dan menguji keefektifan produk Sugiyono (2015, p. 407), dengan model pengembangan Thiagarajan atau biasa disebut 4D (define, design, develop dan desseminate) yang dimodifikasi menjadi 3 tahap yaitu: tahap pendefinisian (define), perancangan (design), dan pengembangan (develop) (Thiagarajan, 1974, p. 5).

Tahap pendefinisian dilakukan untuk menentukan kebutuhan-kebutuhan di dalam proses pembelajaran dengan menganalisis tujuan dan batasan materi serta mengumpulkan berbagai informasi yang diperlukan. Pada tahap pendefinisian dilakukan beberapa langkah yang dimulai dari analisis awalakhir, analisis siswa, analisis konsep, analisis tugas, dan analisis tujuan pembelajaran. 
Pada tahap perancangan, dilakukan pemilihan format dan desain awal LKS. Tahap ini bertujuan untuk merancang prototype awal LKS. Selanjutnya dilakukan tahap pengembangan untuk menghasilkan draft perangkat pembelajaran atau LKS yang sudah direvisi berdasarkan masukan para ahli dan uji coba kepada siswa. Tahap pengembangan dilakukan untuk mengumpulkan data sebagai dasar untuk menetapkan tingkat kevalidan LKS yang sudah dikembangkan dan juga untuk memperoleh masukan langsung berupa respon atau komentar siswa.

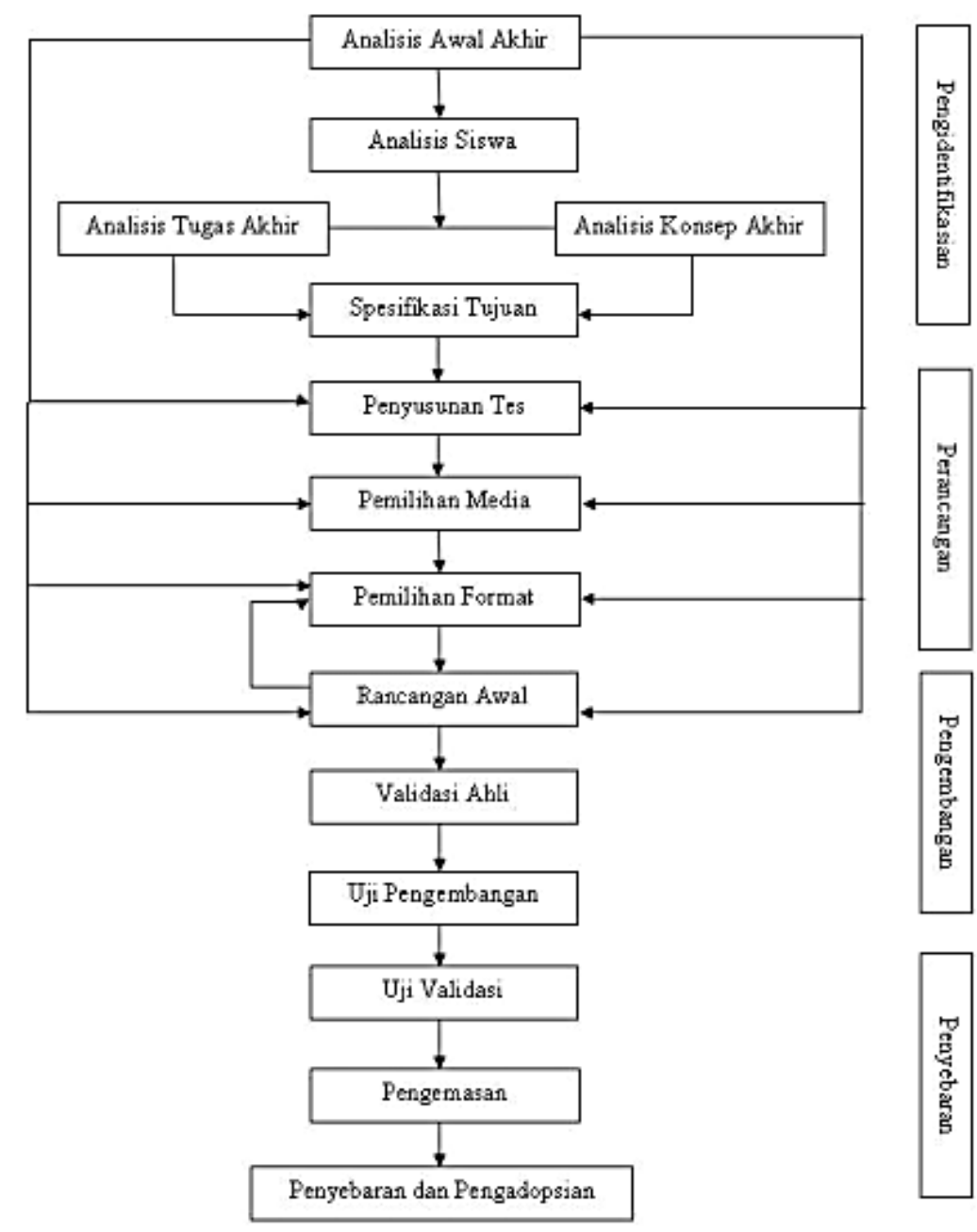

Gambar 1. Prosedur Pengembangan Model 4-D (Thiagarajan, 1974)

Pada tahap ini dilakukan 2 langkah yaitu validasi ahli dan uji coba LKS. Pada tahap validasi ahli ini dilakukan oleh 3 orang validator yaitu 2 dosen dan 1 guru untuk memvalidasi kelayakan LKS yang dikembangkan. Validator memvalidasi LKS berdasarkan validitas muka dan isi. Saran dari validator dianalisis secara deskriptif kualitatif dan digunakan untuk merevisi LKS yang dikembangkan sampai diperoleh LKS yang valid, yaitu apabila semua validator sepakat menyatakan LKS tersebut layak diuji cobakan dan sudah semestinya.

Selanjutnya pada uji coba LKS dilakukan terhadap siswa kelas VIII SMP Negeri 41 Bengkulu Utara untuk memperoleh masukan langsung berupa respon, reaksi dan komentar siswa terhadap LKS. 
Pengembangan Lembar Kerja Siswa untuk Menumbuhkan Kemampuan Pemecahan Masalah Matematis pada Materi Teorema Pythagoras, Yuriska Destania, Selvi Riwayati

Komentar siswa tersebut digunakan untuk mengetahui tingkat kepraktisan LKS dengan menganalisis angket respon siswa menggunakan skala likert (skala bertingkat).

\section{HASIL DAN DISKUSI}

Berdasarkan prosedur pengembangan ada beberapa tahapan yang dilakukan. Tahapan-tahapan yang dilalui dalam penelitian pengembangan LKS ini adalah sebagai berikut:

\section{Tahap Pendefinisian (Define)}

\section{Analisis Awal-Akhir}

Pada tahap ini diperoleh bahwa bahan ajar yang digunakan disekolah adalah buku teks pelajaran yaitu buku paket matematika. Selain itu masih terbatasnya LKS yang memfasilitasi kemampuan penalaran matematisnya. LKS yang ada selama ini kebanyakan hanya sebatas kegiatan yang diambil dari buku paket yang ada dan terkadang hanya berupa rangkuman materi yang sebelumnya telah disampaikan oleh guru. Kurikulum yang dipakai pada sekolah tersebut adalah K13 dan dalam K13 salah satu tujuan pembelajaran yang ingin dicapai adalah kemampuan penalaran matematis siswa. Selanjutnya Materi yang diambil adalah transformasi kelas XI.

\section{Analisis Siswa}

Berdasarkan analisis siswa, kemampuan akademis siswa berbeda-beda. Ada yang berkemampuan tinggi, sedang dan rendah. Pada materi transformasi ini siswa lebih banyak dihadapkan pada permasalahan dengan menggunakan model Learning Cycle $5 E$ dan proses pembelajaran akan menekankan pada kemampuan penalaran matematis siswa.

\section{Analisis Konsep}

Analisis konsep ini berupa peta konsep transformasi yang memetakan kompetensi dasar yang harus dicapai.

\section{Analisis Tugas}

Pada tahap ini peneliti membuat tugas-tugas yang akan diberikan dan dikerjakan siswa selama proses pembelajaran yang sesuai dengan kurikulum serta mengacu pada tujuan pembelajaran.

\section{Analisis Tujuan Pembelajaran}

Berdasarkan hasil analisis konsep dan hasil analisis tugas maka kompetensi dasar dan indikator pencapaian kompetensi dapat disusun pada tahap ini.

\section{Tahap Perancangan (Design)}

\section{Pemilihan Format}

Dalam mengembangkan LKS ini, peneliti mengacu pada struktur LKS secara umum yang meliputi judul, kata pengantar, petunjuk penggunaan, kompetensi inti dan kompetensi dasar yang ingin dicapai, indikator, tujuan pembelajaran. 


\section{Desain Awal}

Yang dilakukan pada tahap ini adalah penulisan draf awal atau LKS awal. Perancangan LKS dan mengacu pada kemampuan pemecahan masalah matematis siswa. Pada tahap ini menghasilkan LKS prototype I.

\section{Tahap Pengembangan (development)}

\section{Validasi Ahli}

Proses validasi dilakukan oleh validator, dimana saran-saran atau komentar dari validator pada prototype 1 akan menjadi bahan untuk merevisi LKS hingga mendapatkan prototype II, dan seterusnya sampai prototype yang valid. Selanjutnya para ahli memvalidasi rancangan awal LKS menggunakan data validasi LKS berupa lembar pertimbangan dan saran atau komentar pada LKS yang terdiri dari aspek validasi bahasa, muka dan isi. Adapun hasil validasi dari para ahli pada uji LKS prototype I masih ada bagian LKS yang belum valid sehingga dilakukan revisi berdasarkan masukan para ahli. Berikut saran komentar validator terhadap LKS prototype I:

Tabel 1. Komentar hasil validasi terhadap LKS prototype I

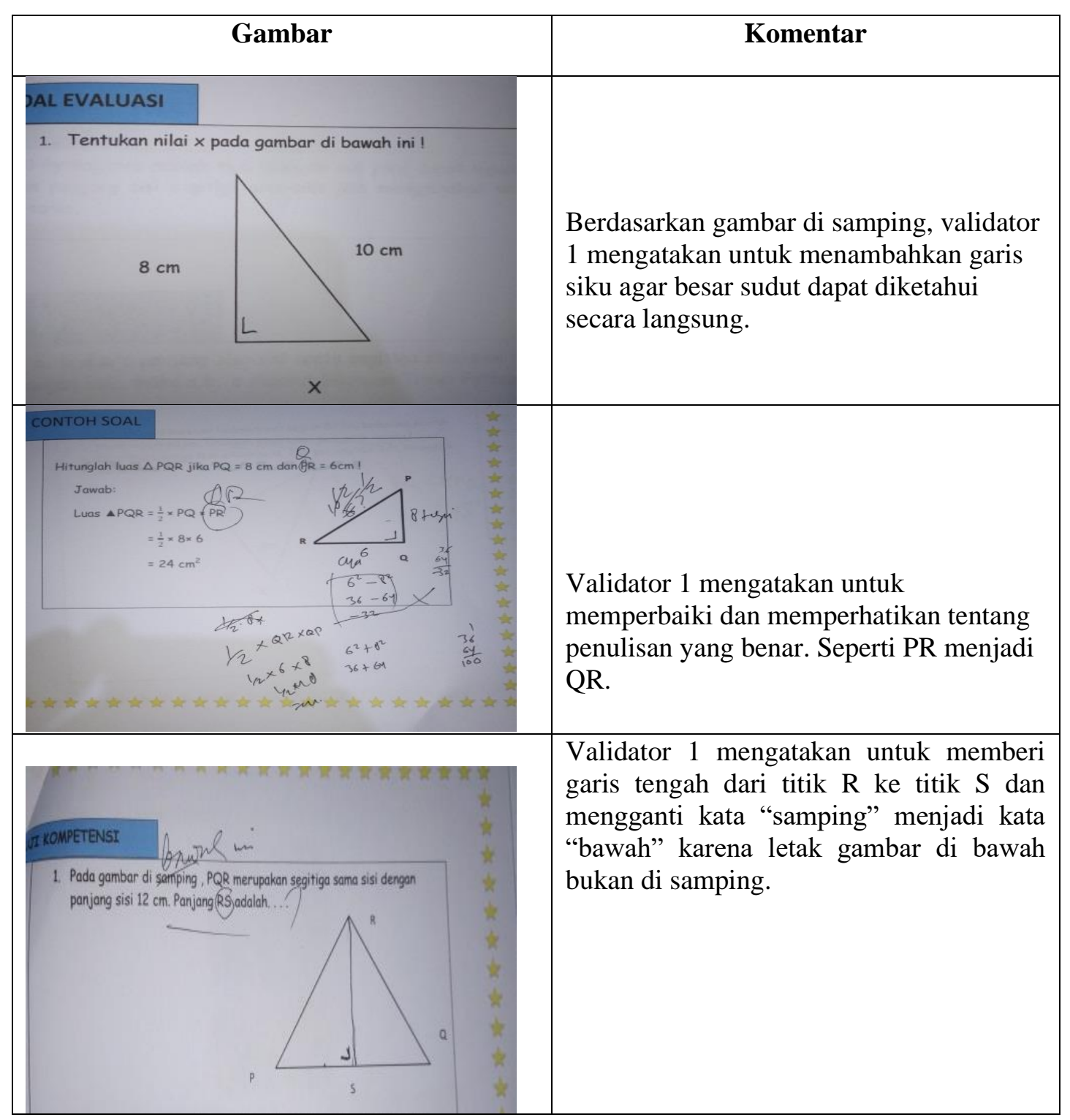




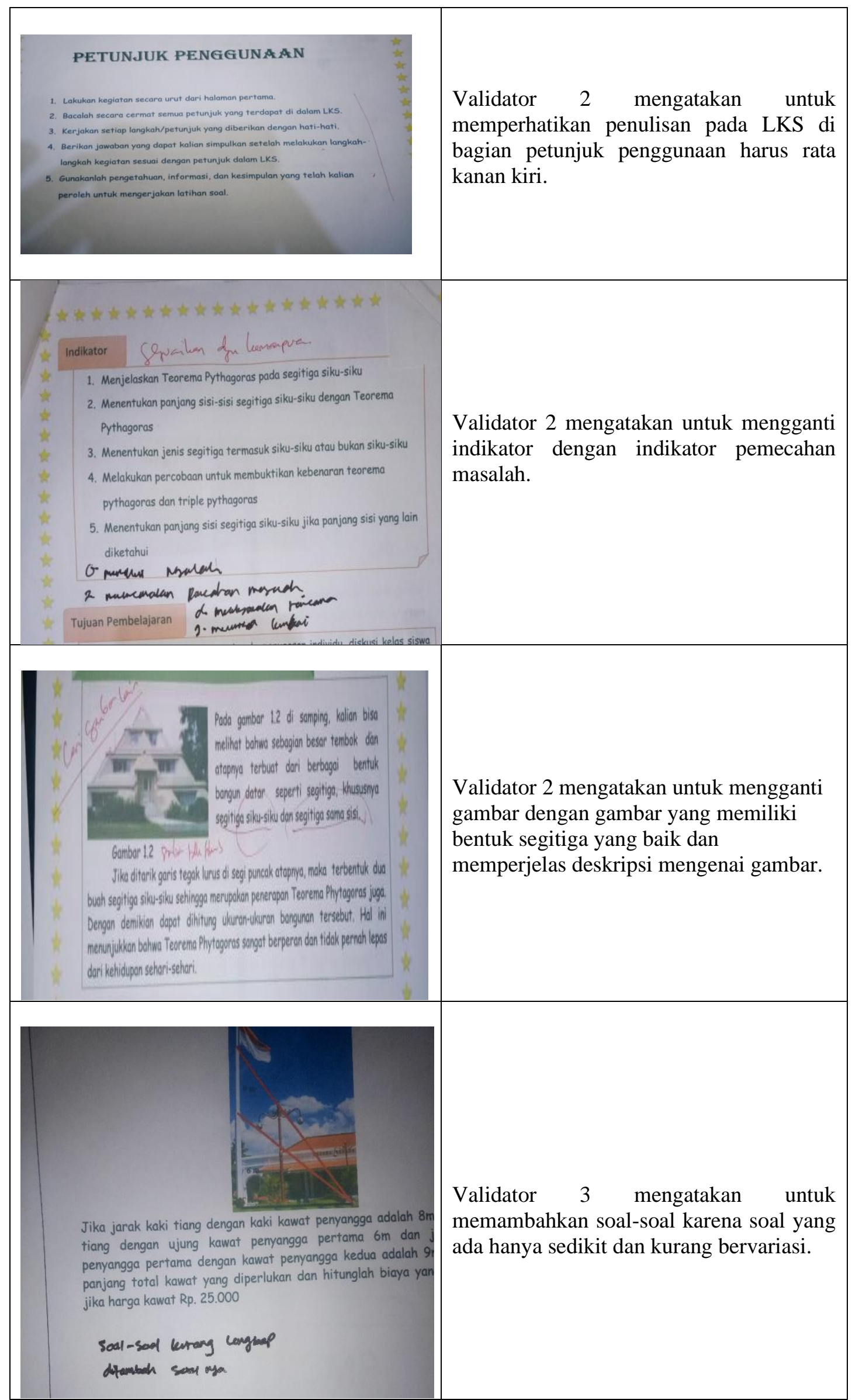




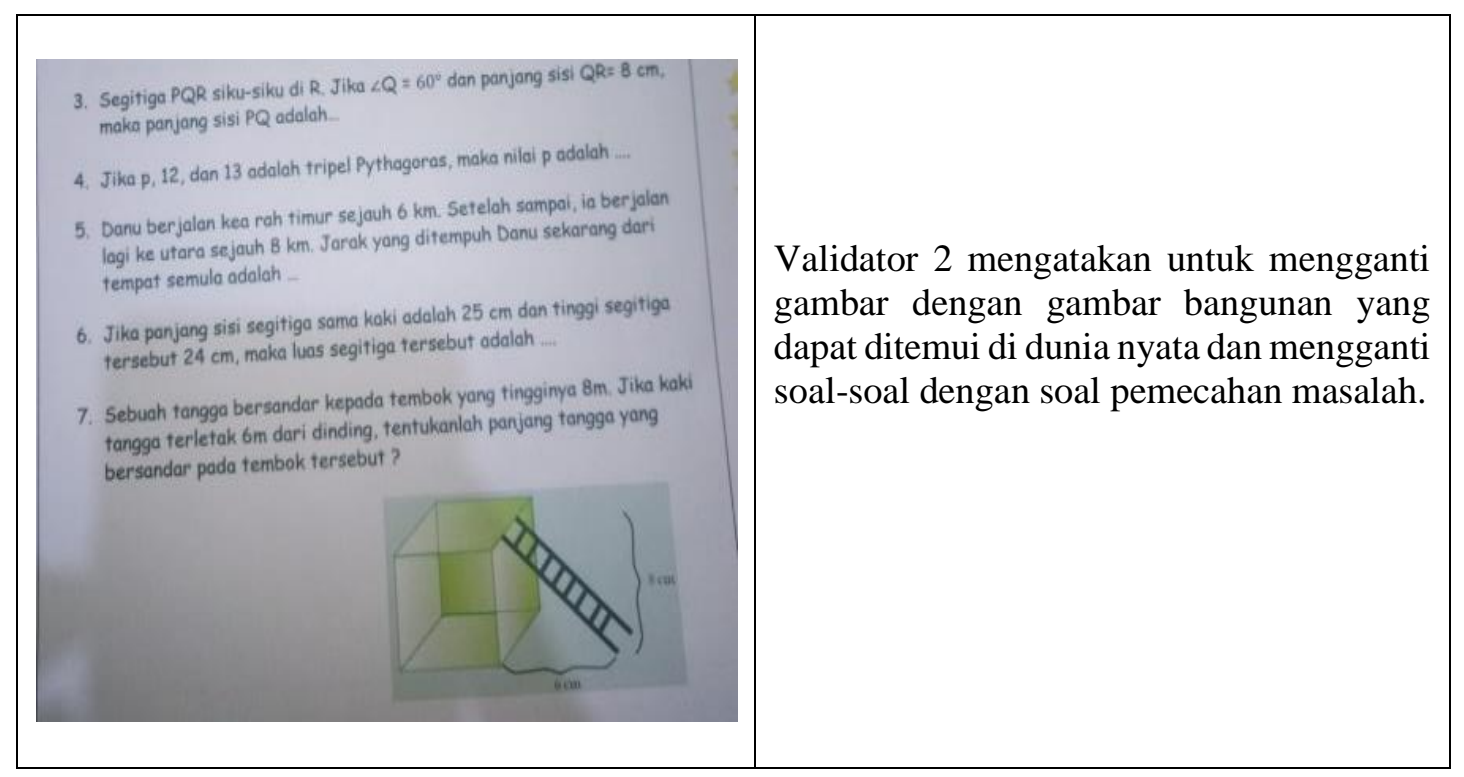

Selanjutnya saran dan komentar tersebut dijadikan bahan untuk merevisi prototype I. Hasil dari prototype I tersebut menghasilkan prototype II. Berikut contoh revisi yang telah dilakukan terhadap prototype I:

Tabel 2. Revisi pada prototype I yang mengasilkan prototype II

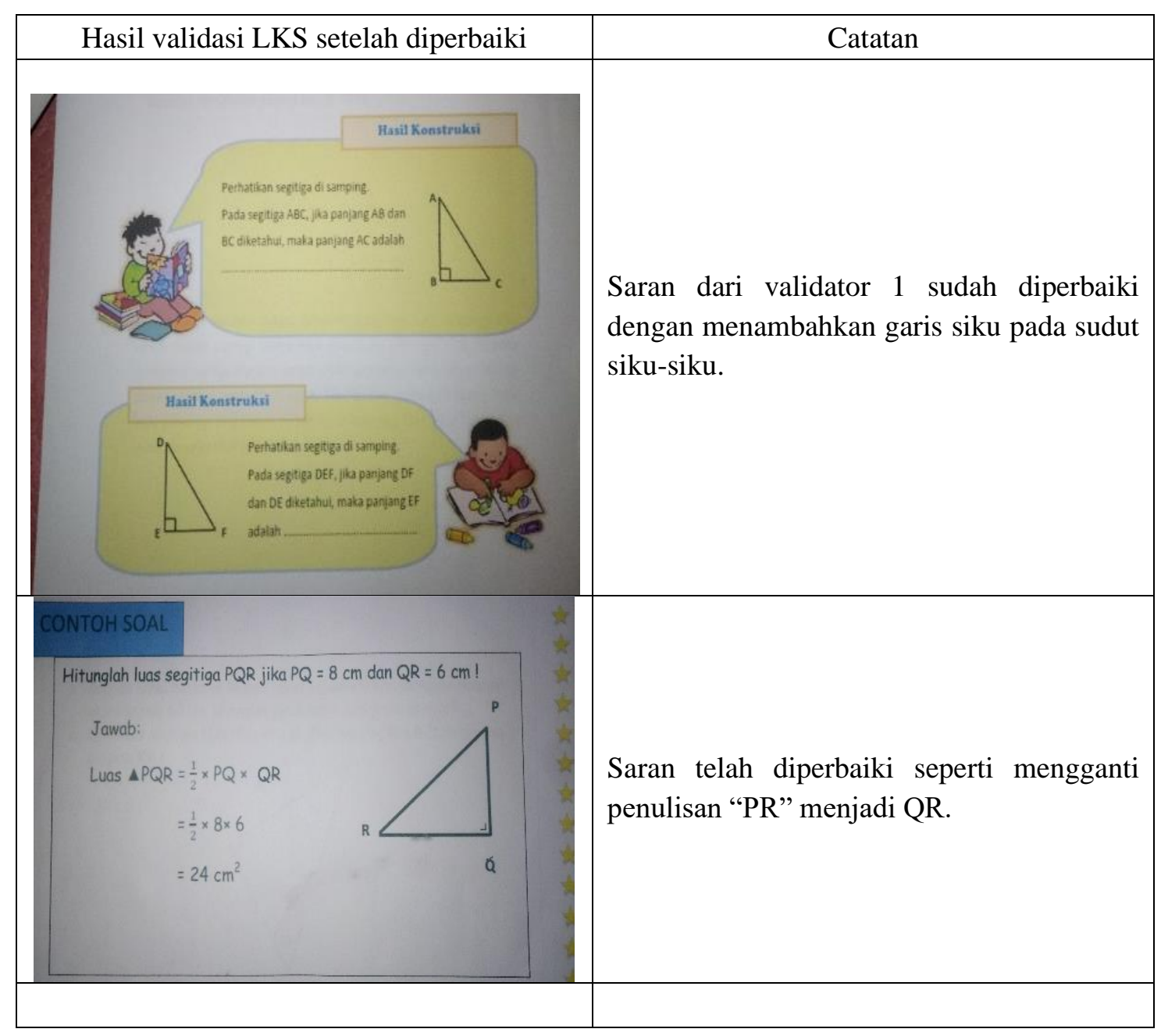




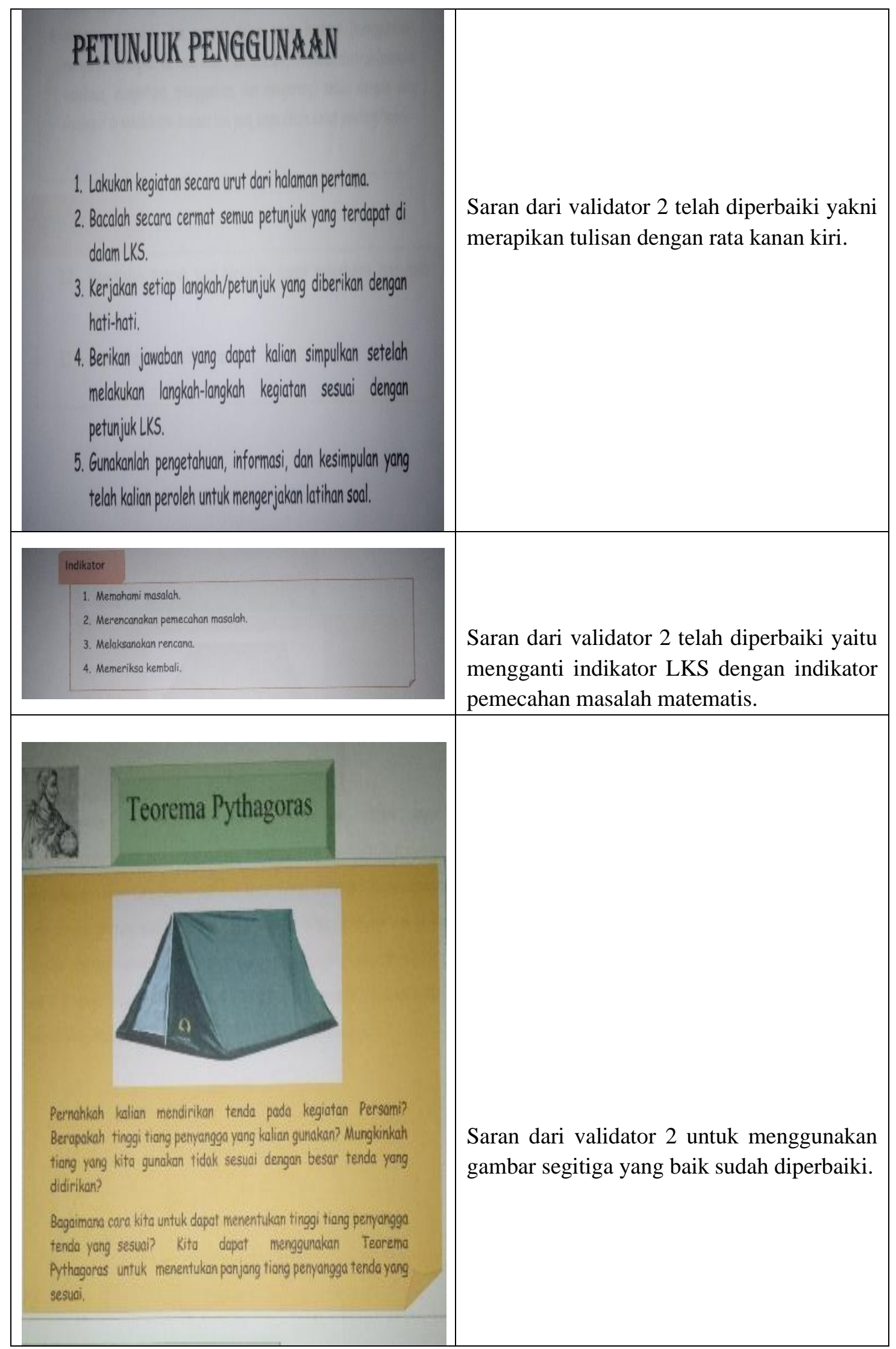




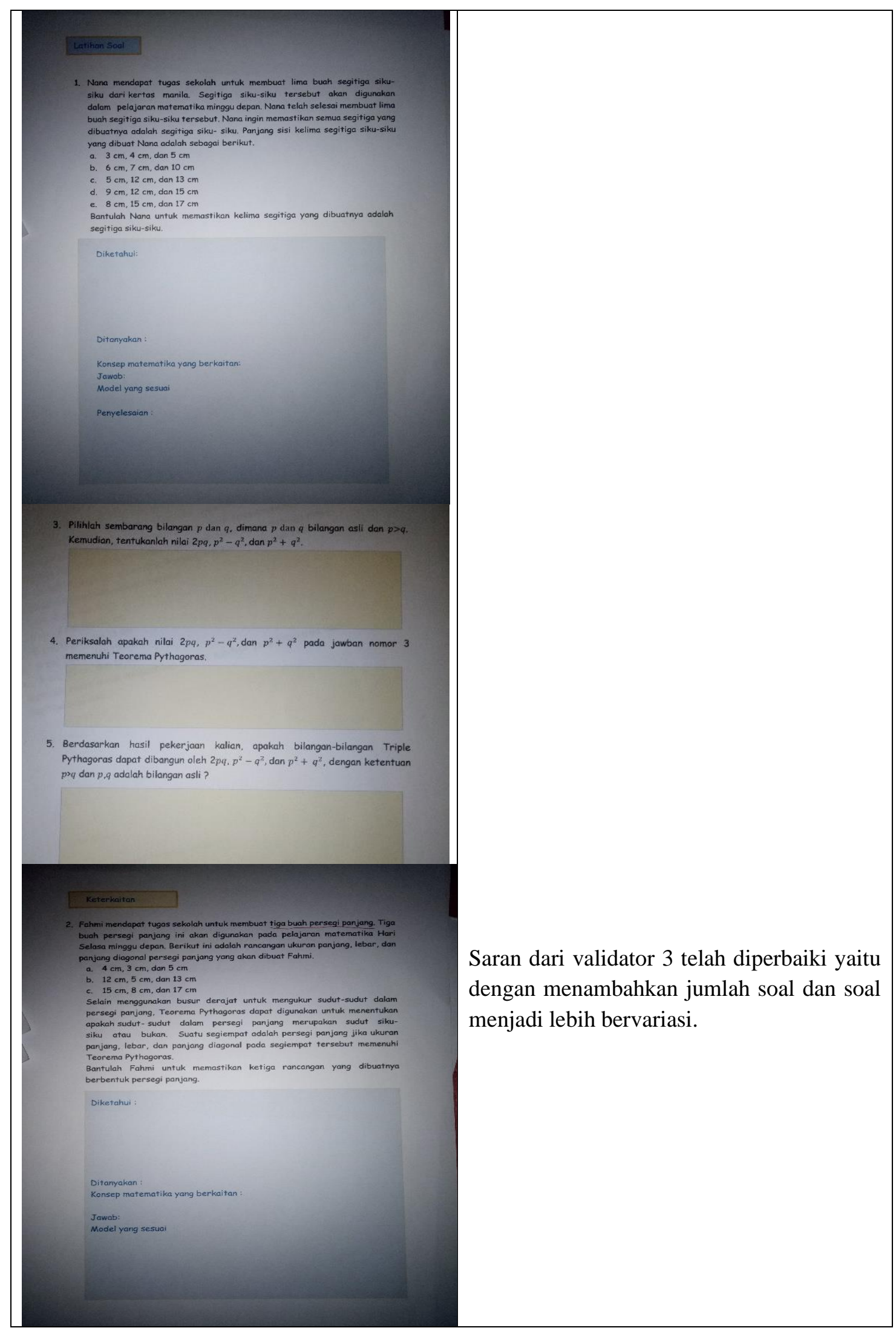

Selanjutnya LKS prototype II divalidasi lagi oleh para validator, dan menurut para validator LKS sudah dinyatakan baik dan valid. Karena pada LKS tidak ada bagian yang harus direvisi lagi, sehingga LKS bisa diuji cobakan. 
Pengembangan Lembar Kerja Siswa untuk Menumbuhkan Kemampuan Pemecahan Masalah Matematis pada Materi Teorema Pythagoras, Yuriska Destania, Selvi Riwayati

\section{Uji Coba Produk}

Terdapat 1 uji coba yang dilakukan yaitu uji coba terbatas untuk menentukan apakah LKS ini praktis. Uji ini dilakukan terhadap 10 orang siswa. Dari uji coba terbatas ini didapatkan data tentang respon siswa terhadap LKS. Berdasarkan angket yang diberikan, rata-rata siswa memberikan respon yang baik. Selanjutnya berdasarkan pertanyaan terbuka, siswa menyatakan bahwa LKS tersebut mudah untuk dipahami.

Analisis kepraktisan dinilai berdasarkan respon siswa terhadap LKS yang dikembangkan. Berikut ini adalah langkah-langkah analisis data kepraktisan tersebut.

1. Untuk memperoleh data kepraktisan dari siswa, peneliti menggunakan tabel penilaian kepraktisan berikut ini:

Tabel 3. Lembar penilaian kepraktisan lembar kerja siswa (LKS)

\begin{tabular}{|c|c|c|c|c|c|c|}
\hline \multirow{2}{*}{ No } & \multirow{2}{*}{ Aspek Yang Dinilai } & \multicolumn{5}{|c|}{ Skor } \\
\hline & & 1 & 2 & 3 & 4 & 5 \\
\hline 1 & Tulisan pada LKS dapat dibaca dengan mudah & & & & & \\
\hline 2 & $\begin{array}{l}\text { Penggunaan Bahasa Indonesia dalam LKS sudah sesuai } \\
\text { dengan kaidah penulisan Bahasa Indonesia }\end{array}$ & & & & & \\
\hline 3 & $\begin{array}{l}\text { Kegiatan pada LKS dilakukan secara runtut dalam melatih } \\
\text { keterampilan siswa }\end{array}$ & & & & & \\
\hline 4 & $\begin{array}{l}\text { Penggunaan gambar dan ilustrasi dalam LKS menunjukkan } \\
\text { makna dari masalah kontekstual yang disajikan }\end{array}$ & & & & & \\
\hline 5 & Penggunaan LKS dapat memotivasi dalam belajar & & & & & \\
\hline
\end{tabular}

Dimodifikasi dari Depdiknas (2008) dan Arsyad (2011)

2. Analisis data ini menggunakan skala likert (skala bertingkat), yaitu pemberian skor 1-5 terhadap pernyataan.

Tabel 4. Skala Penilaian Angket Respon Siswa

\begin{tabular}{|c|c|c|}
\hline No & Pilihan jawaban & Skor \\
\hline 1 & Sangat baik & 5 \\
\hline 2 & Baik & 4 \\
\hline 3 & Cukup baik & 3 \\
\hline 4 & Kurang baik & 2 \\
\hline 5 & Tidak baik & 1 \\
\hline
\end{tabular}

Sumber: Riduwan (2012)

3. Setelah dilakukan penskoran, selanjutnya menghitung rata-rata skor untuk masing-masing aspek yang diamati menggunakan rumus sebagai berikut:

$$
\text { Tingkat praktikalitas }=\frac{\text { skor diperoleh }}{\text { skor tertinggi }} \times 100 \%
$$

(Purwanto, 2017)

4. Kemudian menginterpretasikan data berdasarkan tabel berikut: 
Tabel 5. Interpretasi data praktikalitas LKS

\begin{tabular}{|c|c|c|}
\hline No & Interval & Kriteria \\
\hline 1 & $90 \%-100 \%$ & Sangat praktis \\
\hline 2 & $70 \%-89 \%$ & Praktis \\
\hline 3 & $50 \%-69 \%$ & Cukup praktis \\
\hline 4 & $30 \%-49 \%$ & Kurang praktis \\
\hline 5 & $20 \%-29 \%$ & Tidak praktis \\
\hline
\end{tabular}

Sumber: diadaptasi dari Sugiyono (2013, p. 144)

5. Mengkorvesikan rata-rata skor yang diperoleh menjadi nilai kuantitatif sesuai kriteria klasifikasi ratarata tiap skor tiap aspek menjadi data kualitatif sesuai Tabel 5.

Berdasarkan data hasil angket respon siswa yang telah dianalisis menggunakan skala likert (skala bertingkat), diperoleh nilai rata-rata sebesar 3,88. Berdasarkan kriteria kepraktisan pada tabel 5, dapat disimpulkan bahwa nilai kepraktisan penggunaan LKS tergolong praktis yakni berada pada skor 77,6\%. Peneliti menemukan adanya bibit-bibit efektif dalam LKS, Ini tampak dari hasil validasi dan hasil uji coba produk secara terbatas seperti yang telah di paparkan. Secara garis besar kevalidan LKS adalah LKS yang telah valid dilihat dari validitas muka dan validitas isi serta titik temu antara ketiga validator. Sedangkan kepraktisan LKS secara garis besar adalah LKS yang mengandung pemecahan masalah matematis dan sesuai dengan kebutuhan siswa, baik siswa yang berkemampuan rendah, sedang tinggi. Jadi dapat disimpulkan bahwa berdasarkan hasil uji coba ini mendapatkan respon yang baik dan positif mengenai LKS. Selain itu, siswa juga mengatakan LKS tersebut menarik sehingga memotivasi dan memudahkan siswa dalam memahami materi. Oleh karena itu LKS tidak mengalami revisi sehingga menghasilkan LKS untuk memfasilitasi siswa dalam mengembangkan kemampuan pemecahan masalah matematis.

\section{KESIMPULAN}

Penelitian ini menghasilkan LKS matematika yang valid dan praktis untuk memfasilitasi siswa dalam mengembangkan kemampuan pemecahan masalah matematis pada materi teorema Pythagoras kelas VIII SMP. Untuk valid dilakukan proses validasi LKS kepada ahli pada tahap pengembangan yang dilakukan oleh 3 orang validator secara terus menerus sampai mendapatkan LKS yang valid. Validasi yang dimaksud adalah validasi muka dan isi. Selanjutnya dilakukan uji coba LKS untuk memperoleh masukan langsung berupa respon dan komentar siswa. Angket respon siswa ini digunakan untuk mengetahui tingkat kepraktisan LKS. Karena siswa mampu memahami LKS, maka terdapat indikasi bahwa adanya bibit-bibit efektif dalam LKS.

\section{UCAPAN TERIMA KASIH}

Peneliti mengucapkan syukur kepada Allah SWT karena telah diberikan kelancaran menyelesaikan artikel ini. Terimakasih kami ucapkan kepada Bapak/Ibu validator, Kepala Sekolah, dewan guru dan siswa-siswi Kelas VIII SMP 41 Bengkulu Utara yang sudah memberikan dukungan, izin dan 
Pengembangan Lembar Kerja Siswa untuk Menumbuhkan Kemampuan Pemecahan Masalah Matematis pada Materi

berpartisipasi dalam terlaksananya penelitian ini. Serta terimakasih kepada keluarga dan rekan sejawat yang selalu memberikan dukungan.

\section{REFERENSI}

Anindya.F. (2018). Pengembangan Bahan Ajar. Diktat Mata Kuliah Pengembangan Bahan Ajar.

Arsyad, A. (2011). Media pembelajaran. Jakarta: PT Raja grafindo persada.

Departemen Pendidikan Nasional. (2005). Panduan Pengembangan Model Pembelajaran Berbasis Kompetensi. Direktorat PPTK dan KPT Dirjen Dikti.

Depdiknas. (2008). Panduan Pengembangan Bahan Ajar. Departemen Pendidikan Nasional Direktorat Jendral Menajemen Pendidikan Dasar dan Menengah.

Hadi, S., \& Radiyatul, R. (2014). Metode pemecahan masalah menurut polya untuk mengembangkan kemampuan siswa dalam pemecahan masalah matematis di sekolah menengah pertama. EDUMAT: Jurnal Pendidikan Matematika, 2(1).

Juwita, R. M. P., \& Ariani, N. M. (2020). Lembar Kerja Siswa SMP untuk Kemampuan Pemecahan Masalah Open-Ended Teorema Phytgoras. Vygotsky: Jurnal Pendidikan Matematika Dan Matematika, 2(2), 114-125.

Majid, A. (2012). Perencanaan Pembelajaran Bandung: PT Remaja Rosdakarya.

Martin, W. G. (2000). Principles and standards for school mathematics (Vol. 1). National Council of Teachers of.

Purwanto, M. N. (2017). Psikologi Pendidikan. Bandung: Remaja Rosdakarya.

Putri, H. E. (2017). Pendekatan concrete-pictorial-abstract (CPA), kemampuan-kemampuan Matematis, dan rancangan pembelajarannya. UPI Sumedang Press.

Riduwan, M. B. A. D. (2012). Skala Pengukuran Variabel-variabel Penelitian. Bandung. Bandung: Alfabeta.

Riwayati, S., \& Destania, Y. (2019). Efektifitas Desain Lembar Kerja Mahasiswa Terintegrasi Internet untuk Mengembangkan Kemampuan Penalaran Matematis Mahasiswa. Edumatika: Jurnal Riset Pendidikan Matematika, 2(2), 104-112.

Rusdi, R. (2014). Hakikat dan Konsep-Konsep Dasar Psikologi Pendidikan, Belajar dan Pembelajaran Serta Faktor-Faktor yang Mempengaruhinya. Journal Polingua: Scientific Journal of Linguistics, Literature and Education, 3(2), 156-164.

sugiyono. (2015). Metode Penelitian Pendidikan (Pendekatan Kuantitatif, Kualitatif, dan R\&D). Alfabeta.

Sugiyono. (2013). Metode Penelitian Pendidikan. Alfabeta.

Sumartini, T. S. (2016). Peningkatan kemampuan pemecahan masalah matematis siswa melalui pembelajaran berbasis masalah. Mosharafa: Jurnal Pendidikan Matematika, 5(2), 148-158.

Syaiful, S. (2012). Peningkatan Kemampuan Pemecahan Masalah Matematis Melalui Pendekatan PendidikanMatematika Realistik. Edumatica, 2(1), 36-44. 
Taufan.I. (2018). Model pembelajaran PPS. CV. Jejak.

Teguh, T. (2014). Pengantar Pendidikan. Jakarta: Bumi Aksara.

Thiagarajan, S. (1974). Instructional development for training teachers of exceptional children: A sourcebook. 